\title{
Californian grad students vote to unionize
}

[SAN DIEGO] Graduate students at the Berkeley and Los Angeles campuses of the University of California have voted overwhelmingly for union representation as part of a statewide bid for better pay, benefits and working conditions for teaching assistants.

Elections at the remaining six of the university's campuses are due to be completed next week. A state agency will then count the votes to determine whether other campuses will also be represented by affiliates of the United Auto Workers Union.

The elections follow a 16-year campaign by graduate students at the university to secure union recognition for teaching assistants, who have increasingly played a vital role in academic education, in science, engineering and mathematics. They typically manage laboratory sessions, grade papers and staff offices for professors, who limit their involvement to giving lectures.

During this period, California's two Republican governors contested unionization at every opportunity. But the recent election of Gray Davis, a Democrat supported by unions, whose position gives him direct involvement in the administration of the University of California system, is seen as prompting a change in philosophy.

There has long been discontent among teaching assistants at the university, who complain of excessive workloads and a lack of benefits, such as adequate health insurance and dental and optical cover.

The campus elections have been allowed to proceed in recent weeks when the university's attorneys stopped fighting attempts to organize them, after spending about $\$ 1.7$ million on legal fees in the past four years alone to block teaching-assistant unions.

Similar concerns by teaching assistants have emerged at other campuses around the country. There are unions representing graduate students at some 20 institutions.

Teaching assistants at New York University last month filed a petition with the National Labor Relations Board to hold an election for representation by the United Auto Workers Union.

This petition is believed to be the first such request for union representation by graduate students at a private university. For the past 25 years, the National Labor Relations Board has held that graduate students who perform teaching and research duties are primarily students, and so do not have collective bargaining rights under the National Labor Relations Act.

At New York University, housing and fee reductions are a major issue of concern for the teaching assistants, says Sivan Rottenstreich, who is in his third year of a mathematics doctoral programme at the university's Courant Institute. "The big issue is to

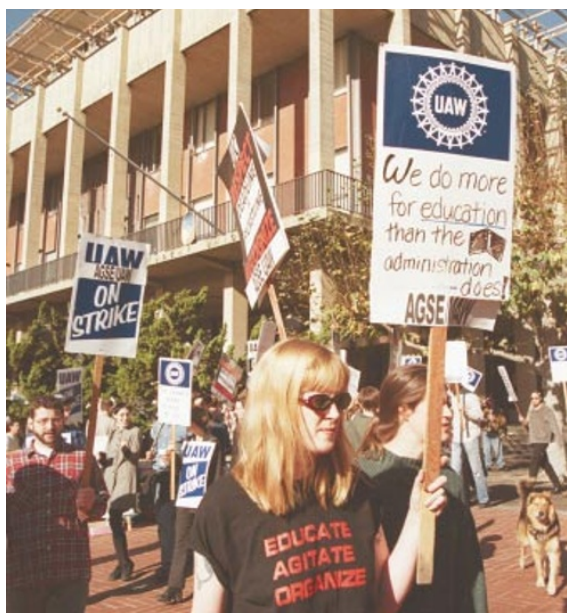

Campus protest: teaching assistants complain of being overworked and lacking health benefits.

have a voice; we can improve this university."

University of California graduate students from San Diego to Berkeley voice widespread displeasure with the workload and lack of input in the workplace. For example, Jenny N. Hyatt, a first-year doctoral student in materials science at San Diego, says that as a teaching assistant she was assigned at times to eight three-hour lab sessions a week, but was being paid to work only 20 hours. "I was

being overworked," says Hyatt. "When I complained, they ignored me."

Most teaching assistants say that faculty members largely remained estranged from the graduate-student organizing effort, with some supportive and some opposed.

The University of California administration has "stalled for a long time in the face of evident student demand for a union," says Michael Watts, director of the Institute for International Studies at Berkeley, who was involved in organizing assistants as a graduate student at the University of Michigan. "There is a need to have a systematic way to regulate workloads, pay and benefits."

Teaching assistants voted by 833 to 293 to unionize at Berkeley. At Los Angeles, there was a similar turnout in March among the 1,700 teaching assistants, who voted by 718 to 269 to unionize. Voting took place last month at San Diego, Irvine, Davis and Santa Cruz, and teaching assistants at Riverside and Santa Barbara will vote in the next week.

Contract negotiations are to begin this summer between the University of California and student groups that vote for a union. There is "absolutely genuine sentiment" to bargain with the teaching assistants, says Joseph Duggan, associate dean of the graduate division at Berkeley.

RexDalton

\section{Reprieve for neutron project in Congress}

[WASHIngton] The Science Committee of the US House of Representatives has agreed to support funding to begin building the Advanced Spallation Neutron Source at Oak Ridge in Tennessee, relieving fears that the project would fail to win money from Congress.

The committee voted unanimously last week to allocate $\$ 100$ million to construction of the project, provided that the Department of Energy meets a list of conditions. Although the money allocated by the committee for the fiscal year 2000 is barely half the amount requested by the Clinton administration in February, the vote was interpreted as a reprieve for the project.

James Sensenbrenner (Wisconsin, Republican), chair of the committee, had previously wanted to withhold funds altogether (see Nature 398, 739; 1999).

On the same day last week, the Senate energy and water appropriations subcommittee, chaired by Pete Domenici (Republican, New Mexico), voted to provide $\$ 169$ million for construction of the project, serving notice that it still has powerful support in Congress. Los Alamos laboratory in New Mexico will build the accelerator that will drive the neutron source.

The Science Committee's compromise was struck after a heated debate on a Democrat amendment to restore $\$ 150$ million to the project, during which it became clear that several Republicans were unhappy with Sensenbrenner's plan to withhold funding.

Republicans Connie Morella (Maryland), Judy Biggert (Illinois) and Vernon Ehlers (Michigan) each spoke for the project, but voted against the amendment to restore funding. Two moderate Republicans, Sherwood Boehlert (New York) and Roscoe Bartlett (Maryland), were absent for the vote, and a third, Joe Barton (Texas), voted with the Democrats.

The result was a vote tied at 17-17, causing the amendment to fail. But it was obvious that the committee did not want to pass a bill with no funding for the project, which has wide support in the scientific community. When the committee broke for lunch, staff thrashed out a compromise that would give the project $\$ 100$ million.

Congressional staff say that the appropriations committees, which have the real budgetary power over the project, are likely to agree to provide at least $\$ 150$ million next year, but will attach conditions to ensure proper management by the energy department.
Colin Macilwain 